DOI

\title{
МОЖЛИВОСТІ РЕНТГЕНОДІАГНОСТИКИ ТА МУЛЬТИДЕТЕКТОРНОЇ КОМП'ЮТЕРНОЇ ТОМОГРАФІЇ В ДІАГНОСТИЦІ ЗМІН КІСТКОВОЇ ТКАНИНИ СТОП ПРИ ХРОНІЧНІЙ АРТЕРІАЛЬНІЙ НЕДОСТАТНОСТІ НИЖНІХ КІНЦІВОК
}

ФВ. М. Мацькевич

\section{ДВНз «Івано-Франківський національний медичний університет»}

РЕЗЮМЕ. Мета - вивчити та порівняти можливості оцінки стану кісткової тканини стоп за допомогою методів кількісної еталонної денситометрії та мультидетекторної комп'ютерної томографії у пацієнтів з хронічною артеріальною недостатністю.

Матеріал і методи. Обстежено і проаналізовано дані променевого обстеження кісткової тканини нижніх кінцівок 40 чоловіків у віці 50-65 років, з ХАННК, викликаною облітеруючим атеросклерозом (ОА). Пацієнтам було проведено КЕД стоп і МДКТ гомілковостопних суглобів.

Результати. 3 посиленням ішемічних змін частота зниження мінеральної щільності кісткової тканини (МщКТ) головок першої та п'ятої плеснових кісток досягали $(50 \pm 3,5)$ \% і $(72 \pm 4,2)$ \% відповідно. Наростання ішемії впливало на градацію зниження МЩКТ і було прямо пропорційним частоті виявлення даних змін.

Висновки. КЕД і МДКТ є високоінформативними методами для діагностики змін МЩКТ у пацієнтів з ХАННК, викликаною ОА. МДКТ стоп була максимально інформативною і переважала над КЕД в диференційованому визначенні стану кісткової тканини.

КлючовІ словА: облітеруючий атеросклероз; хронічна артеріальна недостатність нижніх кінцівок; мінеральна щільність кісткової тканини.

Вступ. Національний інститут серця, легень та крові США (National Heart, Lung and Blood Institute, USA) визначає, що основною нозологічною одиницею при периферійних захворюваннях артерій (ПЗА) $\epsilon$ атеросклероз [4]. Результатом атеросклеротичних змін у нижніх кінцівках $\epsilon$ ішемія, а заключним етапом деструктивних явищ - гангрена [5]. О. І. Нішкумай та співавт., провівши ультразвукову денситометрію п'яткової кістки у пацієнтів з хронічною артеріальною недостатністю нижніх кінцівок (ХАНHК), спричиненою облітеруючим атеросклерозом (OA), відзначили зниження показників SOS, Т-індексу та BUA [1]. Метод кількісної еталонної денситометрії (КЕД) детально вивчений В. В. Поворознюком та співавт., які встановили, що застосування денситометричного еталону дало змогу мінімізувати варіації при визначеннях щільності кортикальної та трабекулярної кісткової тканини [2]. Мультидетекторна комп'ютерна томографія (МДКТ) володіє високою роздільною здатністю для оцінки кортикального та губчастого шарів будь-якої ділянки скелета без накладання навколишніх тканин. У зв'язку з прогресуючим ростом інвалідизації, спричиненої ампутацією частини стопи, залишається актуальним питанням вивчення стану кісткової тканини для оптимізації методу лікування.

Мета дослідження - вивчити та порівняти можливості оцінки стану кісткової тканини стоп за допомогою методів кількісної еталонної денситометрії та мультидетекторної комп'ютерної томографії у пацієнтів з хронічною артеріальною недостатністю.

Матеріал та методи дослідження. Нами о6стежено та проаналізовано дані променевого о6- стеження кісткової тканини нижніх кінцівок 40 осі6 (всі чоловіки) віком 50-65 років з ПЗА нижніх кінцівок, спричиненими ОА, які проявлялись ХАННК, в умовах Івано-Франківської обласної клінічної лікарні і центральної міської клінічної лікарні м. Івано-Франківськ з 2009 р. по 2016 р. Усі пацієнти були нами поділені на дві групи за рівнем транскутанного насичення киснем $\left(\mathrm{TcPO}_{2}\right)$ в ділянці стопи: 1$) 20$ пацієнтів із значеннями транскутанної напруги кисню $\left(\mathrm{TcPO}_{2}\right)$ на стопі >25 мм рт. ст.; 2) 20 пацієнтів із показниками $\mathrm{TCPO}_{2} \leq 25$ мм рт. ст.

Обом групам пацієнтів було проведено наступні радіологічні методи дослідження: 1) кількісну еталонну денситометрію обох стоп; 2) мультидетекторну комп'ютерну томографію гомілковостопних суглобів.

Контрольну групу (КГ) склали 20 практично здорових чоловіків віком від 40 до 50 років з травмами кінцівок. Усі обстежувані особи були детально ознайомлені з методами дослідження та дали підписану інформовану згоду на обстеження.

КЕД проводили за допомогою цифрової рентгенографії обох стоп у двох проекціях із застосуванням східчастого алюмінієвого клинеталону та запропонованої нами математичної обробки отриманих даних (патент на корисну модель № 113226). Рентгенографічне дослідження здійснювали на апараті з приймачем рентгенівського зображення - повноформатним плоскопанельним детектором з системою візуалізації, цифрової обробки та зберігання зображення.

На отриманих цифрових зображеннях на робочій станції, використовуючи програму eFilm, 3 
Огляди літератури, оригінальні дослідження, погляд на проблему

допомогою функції "Tools-Measurements-Elipse", еліпсоподібною апертурою площею (600ะ50) пікселів визначали оптичну щільність кісткової тканини в проекції головок плеснових кісток. Аналогічно цією ж апертурою вимірювали оптичну щільність м'яких тканин медіально від головки першої плеснової кістки. Такою ж апертурою вимірювали оптичну щільність відповідної сходинки алюмінієвого клин-еталону. Отримані дані піддавали математичній обробці згідно із запропонованими нами розрахунками.

МДКТ гомілковостопних суглобів пацієнтам проводили на апаратах “Aquillon Prime” (Toshiba) та Somatom 16 (Siemens) відповідно до протоколу Ankle/Foot. При аналізі стану кісткової тканини вивчали стан кіркової та губчастої речовин в аксіальних та сагітальних площинах: 1) у підошвовій та тильній поверхнях обох п'яткових кісток; 2) у головці та діафізі усіх плеснових кісток обох кінцівок за методикою Д. Робертсона та ін. [6]. При визначенні мінеральної щільності кісткової тканини (МЩКТ) користувались одиницями Хаунсфілда

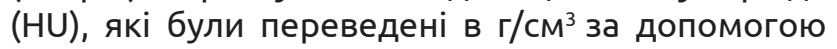
способу визначення біологічної щільності тканин, запатентованого А Н. Чуйком та А. А. Копитовим (RU 2472440) [3].

Результати й обговорення. У досліджуваній групі пацієнтів з ОА та рівнем ТсРО $>25$ мм рт. ст. при проведенні КЕД у 15 чоловіків (75 \%) змін МЩКТ не виявлено, у п'ятьох (25 \%) пацієнтів відзначалось зниження МЩКТ в ділянці головок перших плеснових кісток до $(2,11 \pm 0,08)$ мг/мм ${ }^{3}$ $(21,5 \pm 0,5$ \%) і п'ятих плеснових кісток до

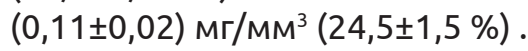

Чутливість методу КЕД, порівняно з МДКТ (прийнятим за стандарт), становила 83,3 \%, специфічність 100 \%, точність 97,5%. Виявлена залежність між фактором та результатом була статистично значимою та суттєвою, так як 95 \% ДІ не включав одиницю - значення його нижньої границі становило 5,071, а верхньої - 241,567 відповідно. Дещо нижча чутливість тесту кількісної еталонної денситометрії може бути пояснена погрішністю вибору щільності м'яких тканин, чого можливо уникнути при МДКТ.

При проведенні МДКТ у 6 пацієнтів досліджуваної групи виявлено зниження МЩКТ в головках перших та п'ятих плеснових кісток. Ці дані корелювали з даними, отриманими при КЕД. У одного пацієнта були виявлені зміни МЩКТ головок плеснових кісток, чого не було візуалізовано за допомогою методу КЕД. Зниження МЩКТ ГР головки перших плеснових кісток у 6 пацієнтів (30 \%) даної групи в середньому становило $(19,5 \pm 0,5)$ \% $((554,64 \pm 12,2) \mathrm{HU})$. У двох пацієнтів додатково було зниження МЩКТ КР головок плеснових кісток на $(18 \pm 0,5) \%$, що становило $(1029,92 \pm 24,32) \mathrm{HU}$ та КР діафізів на $(15,5 \pm 0,3) \%$, що відповідало $(1603,81 \pm 33,1) \mathrm{HU}$ У п'ятих плеснових кістках зниження ГР МЩКТ становило $(25,5 \pm 0,8) \%$, що відповідало $(414,9 \pm 12)$ НU. Також додатково зниження МЩКТ КР головок п'ятих плеснових кісток на $(21 \pm 0,3) \%((1027,79 \pm 14,5) \mathrm{HU})$ було у 2 осіб. Змін КР діафізів цих кісток не відзначалось.

При проведенні кореляційно-регресивного аналізу для порівняння методів кількісної еталонної денситометрії стоп та МДКТ стоп встановлено, що коефіцієнт кореляції Пірсона (г) дорівнює 0,788. Зв'язок між досліджуваними ознаками (МЩКТ, заміряною за допомогою МДКТ, та МЩКТ, отриманою при КЕД) є прямим; сила зв'язку за шкалою Чеддока $є$ високою. Коефіцієнт детермінації ${ }^{2}$ становить 0,620, що свідчить про сильну кореляцію двох змінних між собою. Залежність ознак $\epsilon$ статистично значимою $(p<0,05)$.

При проведенні КЕД обох стоп 31 кінцівки (9 з 40 пацієнтів мали часткові ампутації однієї стопи) у 8 осіб (40\%) з рівнем ТрСО виявлено зниження МЩК у порівнянні з КГ (рис. 1). Дані зміни відзначались у головках всіх плеснових кісток і, як показала в подальшому МДКТ, знижувалась щільність і ГР (у 100 \% випадків), і КР (у 85 \% випадків). Зниження в ГР головок перших, других, третіх плеснових кісток у середньому становило 45-64 \%; у п'ятих плеснових кістках зниження МЩКТ було найвираженіше - до $(72 \pm 4,2) \%$. МЩКТ КР головок плеснових кісток в середньому знижувалась на $(31 \pm 4,7)$ \%. При проведенні МДКТ ви-

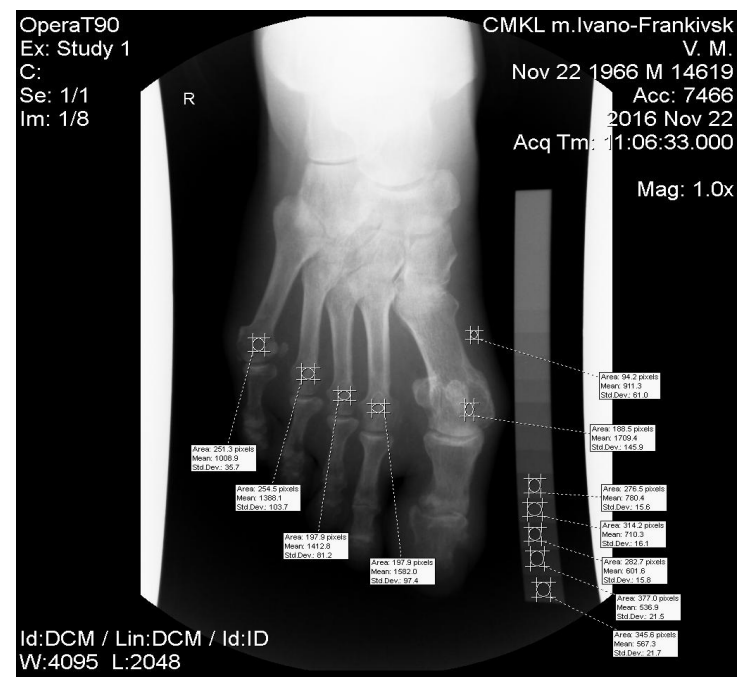

Рис. 1. Кількісна еталонна денситограма правої стопи пацієнта Ш., 50 років, з діагнозом ОА обох нижніх кінцівок, ХАН III-IVст. При КЕД виявлено зниження МщК в головках першої (на 55,5 \%), другої (на 47,6 \%), третьої (на 34 \%) та п'ятої (на 71,4 \%) фаланг правої стопи. 
Огляди літератури, оригінальні дослідження, погляд на проблему

явлено зниження МЩКТ головок плеснових кісток ще у 2 пацієнтів, чого не було візуалізовано методом КЕД (рис. 2). лено, що коефіцієнт кореляції Пірсона (г) дорівнює 0,944. Зв'язок між досліджуваною МЩКТ, заміряною за допомогою МДКТ та МЩКТ,

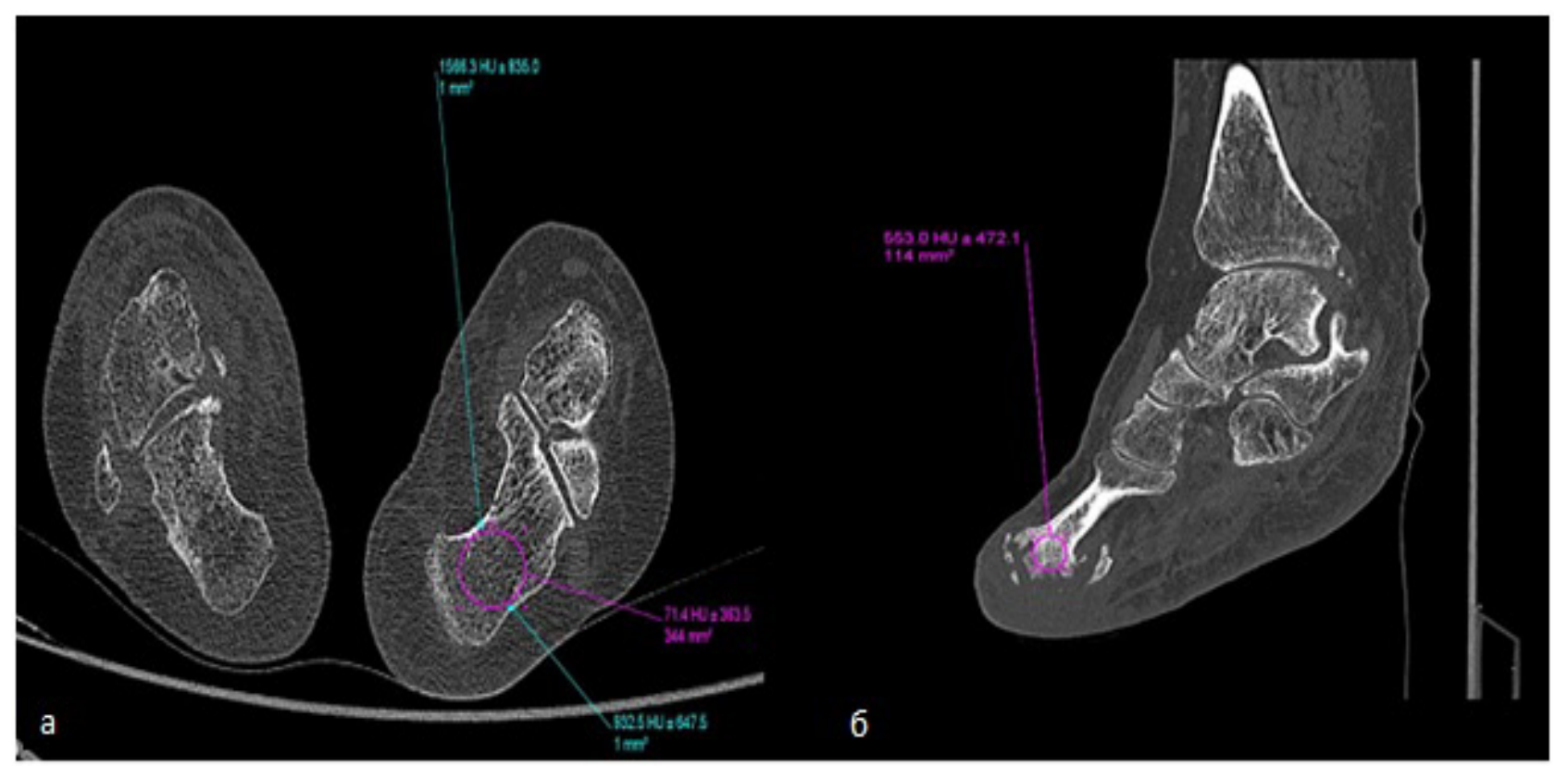

Рис. 2. МДКТ стоп пацієнта Г., 63 роки, з діагнозом критичної ішемії лівої стопи ХАН IV стадії. Гангрена лівої кукси: а) зниження МЩКТ ГР лівої п'яткової кістки на 65,4 \%; 6) деструктивні зміни кісткової тканини та зниження МЩКТ ГР на 19,8 \% в головці першої плеснової кістки лівої стопи.

Також у чотирьох пацієнтів (20\%) відзначалось зниження МЩКТ п'яткової кістки, а саме її губчастої речовини, на $(18 \pm 1,01)$ \% $((609,26 \pm 21,3) \mathrm{HU})$ порівняно 3 контрольною групою.

Чутливість методу КЕД становила 80 \%, специфічність $100 \%$, точність $95 \%$. Виявлена залежність між фактором та результатом $\epsilon$ статистично значимою та суттєвою, оскільки 95 \% ДІ не включає одиницю $(4,181 ; 61,222)$.

При порівнянні двох груп чоловіків з ОА та рівнями ТсРО $2>25$ мм рт. ст. та $\leq 25$ мм рт. ст. слід зазначити, що частота зниження МЩКТ більша у пацієнтів з ТсPO $2 \leq 25$ мм рт. Ст., тобто чим нижчий ТсPО тим більше осіб має знижений рівень МЩКТ. Також ступінь зниження МЩКТ залежить від посилення та тривалості ХАН.

При проведенні кореляційно-регресивного аналізу для порівняння методів кількісної еталонної денситометрії стоп та МДКТ стоп встанов- отриманою при КЕД, є прямим; сила зв'язку за шкалою Чеддока $\epsilon$ досить високою. Коефіцієнт детермінації ${ }^{2}$ становить 0,891, що свідчить, про сильну кореляцію двох змінних між собою. Залежність ознак $\epsilon$ статистично значимою $(p<0,05)$.

Отримані дані КЕД корелюють щодо специфічності і чутливості із результатами датських вчених, які застосовували КЕД як скринінговий метод у виявленні остеопорозу у чоловіків [7]. Згідно з їх результатами, AUC при ROC-аналізі даного методу досягала 0,75.

Висновки. КЕД та МДКТ $є$ високоінформативними методами для діагностики змін МЩКТ у пацієнтів з ХАННК, спричиненою ОА. Метод МДКТ переважав КЕД завдяки можливості пошарового дослідження та відділення м'яких тканин.

Перспективи подальших досліджень. Дослідити наявність залежності та взаємозв'язку між станом судинного русла та кісткової тканини нижніх кінцівок у пацієнтів з ХАН, спричиненою ОА.

\section{ЛІТЕРАТУРА}

1. Нишкумай О. И. Изменение структурно-функционального состояния костной ткани у больных с облитерирующим атеросклерозом артерий нижних конечностей / О. И. Нишкумай, Н. Г. Строило, А. Б. Строило // Проблеми остеології. - 2010. - № 4. - С. 21-26.
2. Поворознюк В. В. Фактори ризику розвитку остеопорозу. Роль FRAX в оцінці індивідуального ризику переломів / В. В. Поворознюк, Т. Р. Машталер, Р. Т. Машталер // Проблеми остеології. - 2010. - № 4. - С. 3-12.

3. Чуйко А. Н. Компьютерная томография и 
Огляди літератури, оригінальні дослідження, погляд на проблему

основные механические характеристики костных тканей / А. Н. Чуйко, А. А. Копытов, А. А. Копытов // Медицинская визуализация. - 2012. - № 1. - С. 102-107.

4. Outcomes and risk prediction model for peripheral arterial disease in patients with stable coronary artery disease / A. O. Badheka, A. D. Rathod, A. S. Bharadwaj [et al.] // Angiology. - 2011. - № 62. - P. 473-479.

5. Fishbein M. C. Arteriosclerosis: facts and fancy / M. C. Fishbein, G. A. Fishbein, D. Geffen // Cardiovascular
Pathology. - 2015. - № 24. - P. 335-342.

6. Structural changes in the forefoot of individuals with diabetes and a prior plantar ulcer / D. D. Robertson, M. J. Mueller, K. E. Smith [et al.] // The Journal of Bone \& Joint Surgery. - 2002. - № 8. - P. 1395-1404.

7. Radiographic absorptiometry as a screening tool in male osteoporosis: results from the Odense Androgen Study / S. J. Hansen, M. M. Nielsen, J. Ryg [et al.] // Acta. Radiologica. - 2009. - № 6. - P. 658-663.

\section{REFERENCES}

1. Nishkumay, O.I., Stroilo, N.G., \& Stroilo, A.B. (2010). Izmeneniia strukturno-funktsionalnogo sostoianiia kostnoi tkani u bolnykh s obletiriruiushchim aterosklerozom arterii nizhnikh konechnostei [Changing the structural and functional condition of bone tissue in patients with obliterating atherosclerosis of the lower extremities]. Problemy osteolohii - Problems of Osteology, 4, 21-26 [in Russian].

2. Povorozniuk, V.V., Mashtaler, T.G., Mashtaler, R.T. (2010). Faktory ryzyku rozvytku osteoporozu. Rol FRAX $\mathrm{v}$ otsintsi indyvidualnoho ryzyku perelomiv [Risk factors for osteoporosis. FRAX role in assessing individual risk of fractures]. Problemy osteolohii - Problems of Osteology, 4, 3-12 [in Ukrainian].

3. Chuyko, A.N., Kopytov, A.A., \& Kopytov, A.A. (2012). Kompiuternaia tomografiia i osnovnyie mekhanicheskiie kharakteristiki kostnykh tkanei [Computed tomography and main mechanic characteristic of bone tissues].

Meditsynskaia vizualizatsiia - Medical Visualization 1, 102107 [in Russian].

4. Badheka, A.O., Rathod, A.D., \& Bharadwaj, A.S. (2011). Outcomes and risk prediction model for peripheral arterial disease in patients with stable coronary artery disease. Angiology, 62, 473-479.

5. Fishbein, M.C., Fishbein, G.A., \& Geffen, D. (2015). Arteriosclerosis: facts and fancy. Cardiovascular Pathology, 24, 335-342.

6. Robertson, DD., Mueller, M.J., Smith K.E. (2002). Structural changes in the forefoot of individuals with diabetes and a prior plantar ulcer. The Journal of Bone \& Joint Surgery, 8, 1395-1404.

7. Hansen, S.J., Nielsen, M.M., \& Ryg, J. (2009). Radiographic absorptiometry as a screening tool in male osteoporosis: results from the Odense Androgen Study. Acta Radiologica, 6, 658-663.

\section{ВОЗМОЖНОСТИ РЕНТГЕНОДИАГНОСТИКИ И МУЛЬТИДЕТЕКТОРНОЙ КОМПЬЮТЕРНОЙ ТОМОГРАФИИ В ДИАГНОСТИКЕ ИЗМЕНЕНИЙ КОСТНОЙ ТКАНИ СТОП ПРИ ХРОНИЧЕСКОЙ АРТЕРИАЛЬНОЙ НЕДОСТАТОЧНОСТИ НИЖНИХ КОНЕЧНОСТЕЙ}

\section{๑В. Н. Мацькевич}

ГВУз «Ивано-Франковский национальный медицинский университет»

РЕЗЮМЕ. Цель - изучить и сравнить возможности количественной оценки состояния костной ткани стоп с помощью методов количественной эталонной денситометрии (КЭД) и мультидетекторной компьютерной томографии (МДКТ) у пациентов с хронической артериальной недостаточностью нижних конечностей (ХАННК).

Материал и методы. Обследованы и проанализированы данные лучевого обследования костной ткани нижних конечностей 40 мужчин в возрасте 50-65 лет, с ХАННК, вызванной облитерирующим атеросклерозом (ОА). Пациентам было проведено КЭД стоп и МДКТ голеностопных суставов.

Результаты. С усилением ишемических изменений частота снижения минеральной плотности костной ткани (МПКТ) головок первой и пятой плюсневых костей достигала $(50 \pm 3,5)$ \% и $(72 \pm 4,2)$ \% соответственно. Нарастание ишемии влияло на градацию снижения МПКТ и было прямо пропорционально частоте выявления данных изменений.

Выводы. КЭД и МДКТ являются высокоинформативными методами для диагностики изменений МПКТ у пациентов с ХАННК, Вызванной ОА. МДКТ стоп была максимально информативной и преобладала над КЭД в диференцированном определении состояния костной ткани.

КЛючЕВЫЕ СЛОВА: облитерирующий атеросклероз; хроническая артериальная недостаточность нижних конечностей; минеральная плотность костной ткани. 
Огляди літератури, оригінальні дослідження, погляд на проблему

\section{THE RADIOGRAPHY AND MULTIDETECTOR COMPUTED TOMOGRAPHY ABILITIES IN DIAGNOSTIC OF BONE TISSUE CHANGES OF THE FEET AT CHRONIC ARTERIAL INSUFFICIENCY OF LOWER LIMBS}

\section{@V. M. Matskevych}

\section{Ivano-Frankivsk National Medical university}

SUMMARY. The aim - to investigate and compare the ability of quantitative assessment of bone tissue of feet using methods standard quantitative densitometry (SQD) and multidetector computed tomography (MDCT) in patients with chronic arterial insufficiency lower limbs (CAILL).

Methods. The radiology examination data of bone tissue of the lower limbs are studied and analyzed in 40 men aged 50-65 years, with CAILL caused by atherosclerosis obliterants (AO). Patients were conducted SQD of feet and MDCT ankle joints.

Results. It is noted that with ischemic changes increasing the frequency of decreasing in bone mineral density (BMD) of the first and fifth metatarsal heads had reached $(50 \pm 3.5) \%$ and $(72 \pm 4.2) \%$ respectively. An increasing ischemia had an effect on the gradation reduction in BMD and it was directly proportional to the frequency of detection of these changes.

Conclusions. SQD and MDCT are highly informative methods for the diagnosis of changes in bone mineral density in patients with CAILL caused by AO. MDCT of ankle joints was the most informative and prevailed over SQD in differentiated determining of bone condition.

KEY WORDS: atherosclerosis obliterants; chronic arterial insufficiency lower limbs; bone mineral density. 